\title{
A COMPARATIVE STUDY ON SOME PROPERTIES AND OXIDATION STABILITY DURING STORAGE OF BUTTER PRODUCED FROM DIFFERENT ANIMALS' MILK
}

\author{
Deren Tahmas Kahyaoğlu ${ }^{1}$, Songül Çakmakçı, \\ ${ }^{1}$ Kastamonu University, Faculty of Engineering and Architecture, Department of Food Engineering, Kastamonu, \\ Turkey \\ ${ }^{2}$ Atatürk University, Faculty of Agriculture, Department of Food Engineering, Erzurum, Turkey
}

Received / Geliş: 20.08.2017; Accepted / Kabul: 02.02.2018; Published online / Online bask1: 08.03.2018

Tahmas Kahyaoğlu, D., Çakmakçı, S. (2018). A comparative study on some properties and oxidation stability during storage of butter produced from different animals' milk. GIDA (2018) 43 (2): 283-293 doi: 10.15237 /gida.GD17081

\section{ABSTRACT \\ In this study, butter produced from cow, sheep and goat cream and was examined during a 90 day storage period at $4^{\circ} \mathrm{C}$. A total of 42 samples produced and were analysed at $1^{\text {st }}, 15^{\text {th }}, 30^{\text {th }}, 45^{\text {th }}, 60^{\text {th }}, 75^{\text {th }}$ and $90^{\text {th }}$ days. It was found that butter type and storage period had significant effect on the $\mathrm{pH}$ value, titratable acidity, acid value, fat constants, peroxide and thiobarbituric acid values, $\beta$-carotene and vitamin $A$ amounts of the butter samples. The $\mathrm{pH}$ value, iodine number, $b$ value and vitamin A amounts decreased during the storage in all the types of butter, whereas titratable acidity, acid value, Reichert-Meissl, Polenske and saponification numbers and oxidation increased. $\beta$-carotene was detected only in butter produced from cow milk creams which decreased during storage. Sensory analysis points decreased in all the butter samples during the storage the highest point belonging to the butter produced from cows' milk. \\ Keywords: Butter, Oxidation stability, Vitamin, Storage, Butter analysis \\ FARKLI HAYVAN SÜTLERİNDEN ÜRETIILEN TEREYAĞLARININ DEPOLAMA SÜRESINCE OKSİDASYON STABİLITTESİ VE BAZI ÖZELLİKLERİ ÜZERİNE KARŞILAŞTIRMALI BİR ARAŞTIRMA}

ÖZ

$\mathrm{Bu}$ araştırmada, inek, koyun ve keçi sütü kremasından üretilen tereyağları, $4^{\circ} \mathrm{C}$ 'de 90 günlük muhafaza süresince incelendi. Toplam 42 tereyağ1 örneği 1., 15., 30., 45., 60., 75. ve 90. günlerde analiz edildi. Tereyağ çeşidi ve depolama süresinin, tereyağ örneklerinin $\mathrm{pH}$ değeri, titrasyon asitliği, asit değeri, yağ sabitleri, peroksit ve tiyobarbitürik asit değerleri, $\beta$-karoten ve A vitamini miktarları üzerinde önemli etkisi olduğu bulundu. $\mathrm{pH}$ değeri, iyot sayıs1, $b$ değeri ve A vitamin miktarı bütün tereyağ1 örneklerinde depolama süresince azalırken, titrasyon asitliği, asit değeri, Reichert-Meissl, Polenske ve sabunlaşma sayıları ve oksidasyon tüm tereyağı çeşitlerinde depolama süresince arttı. $\beta$-karoten sadece inek sütü kremasından üretilen tereyağında bulundu. Bütün tereyağ1 örneklerinde depolama süresince duyusal puanlar azaldı, en yüksek puanları inek sütünden üretilen tereyağları aldı.

Anahtar kelimeler: Tereyağı, Oksidasyon stabilitesi, Vitamin, Depolama, Tereyağı analizleri

\footnotetext{
${ }^{*}$ Corresponding author / Yazışmalardan sorumlu yazar;

\cakmakci@atauni.edu.tr ; songulcakmakci@hotmail.com @ (+90) 442231 2491, 冒 (+90) 4422315878
} 


\section{INTRODUCTION}

Butter is a popular and high-fat dairy product that is usually made from cow's milk. It can also be produced from the milk of goats, sheep or buffalo. It has a pleasant and distinctive taste and odour. It can melt at body temperature, is easily digestible, and includes essential fatty acids, vitamin $\mathrm{A}$ and/or $\beta$-carotene. It is an important energy source, short-chain fatty acids are supply energy rapidly and has a very important place in human nutrition (IDF, 2008). There is an increase in demand for goat milk especially in developed countries due to allergy and gastro-intestinal disorders caused by cow's milk (Haenlein, 2004). Goat's milk presents some important functions in butter manufacture. It has a higher fat content of different composition and structure than that of cow's milk fat. The mostly short-chain fatty acids such as caproic, caprilic, and capric impart a characteristic odour, flavour, and texture to the goat's milk butter (Barlowska et al., 2001; Poutzalis et al., 2016). On the other hand, goat's milk butter has a characteristic white colour due to absence of carotenoids (Rodriguez et al., 2003). Because goats transform all $\beta$-carotene to vitamin A in the milk, goat milk is whiter than cow milk (Park et al., 2007). Goat and sheep milk have higher amounts of vitamin A than cow milk. In terms of the chemical composition, sheep milk is richer than any other milk type. It has a greater amount of lecithin and it is also rich in riboflavin though poor in vitamin $\mathrm{C}$ and nicotinic acid (Raynal-Ljutovac et al., 2008). Significant changes may occur to butter flavour during storage as a result of lipolysis and oxidation processes (Kashaninejad et al., 2017). Lipid oxidation is undesirable in most foods due to quality deterioration that includes changes in appearance, texture, shelf life and nutritional profiles, and development of off-flavours and potentially toxic reaction products (Öztürk and Çakmakçı, 2006; Lim et al., 2015). Acidity and peroxide value are the most used parameters to determine these processes (Povolo and Contarini, 2003). $\beta$ carotene is an oil-soluble, natural pigment of many oils and has strong antioxidant activity. Thus, $\beta$-carotene captures free radicals, delaying potentially harmful oxidative reactions (Karabulut, 2010). The physico-chemical properties of the butter are also related by the animal species. Thus, storage conditions are an important factor for preserving butter for consumption. The aim of this study were to determine the chemical properties, fat constants, oxidation stability, vitamin $A$ and $\beta$-carotene amounts, colour and sensory properties of the butter samples made from cows', sheeps' and goats' milk during the storage period and to contribute to the literatures comparing the differences among these butter.

\section{MATERIALS AND METHODS \\ Materials}

The cream used in the butter production was obtained locally from cows', sheeps' and goats' milk that were reared on the same vegetation of highlands of Erzurum Çat district, Turkey. Mesophilic aromatic starter culture containing Lactococcus lactis subsp. cremoris, Lactococcus lactis subsp. lactis, Lactococcus lactis subsp. lactis biovar diacetylactis and Leuconostoc mesenteroides subsp. cremoris was used for the butter production. The starter culture was obtained from PeymaHansen's Rennet Industry and Trade Inc. (İstanbul, Turkey) via its code DVS (50) $\mathrm{CH}$ Normal 22 (LD).

Stages of the preparation of fat samples are as follows: $50 \%$ fat cream (from cow's, sheep's and goat's milk); Pasteurization $\left(85^{\circ} \mathrm{C}, 5\right.$ minutes) and cooling $\left(18-20^{\circ} \mathrm{C}\right)$; Addition of starter culture $(50$ units/500 kg); Ripening; Churning $\left(14-16^{\circ} \mathrm{C}\right)$; Washing with water; Mixing; Packaging (250 $\mathrm{g}$ for each storage period, first coating with stretch film, then wrapping with aluminium foil); Storage ( $4 \pm$ $\left.1^{\circ} \mathrm{C}\right)$; Analysis $\left(1^{\text {st }}, 15^{\text {th }}, 30^{\text {th }}, 45^{\text {th }}, 60^{\text {th }}, 75^{\text {th }}\right.$ and 90th days).

The butter samples are coded as follows: C: butter made from cow's milk cream; $\mathrm{S}$ : butter made from sheep's milk cream; G: butter made from goat's milk cream.

\section{Physico-chemical analysis and oxidation test methods}

Dry matter and fat content of the butter samples were determined according to the methods used by Kurt et al. (2007) while $\mathrm{pH}$ and titratable acidity (lactic acid, \%) were determined according to the methods used by Atamer (1993). Acid 
value, iodine number, saponification number, refractive index, Reichert-Meissl number and Polenske number were determined according to the standard methods (AOAC, 1995). Thiobarbituric acid value (TBA value) was determined as described by Öztürk and Çakmakç1 (2006) as mg malonaldehyde/kg butter. Peroxide value (PV) was determined as described by Atamer (1993).

\section{Colour analysis}

During the storage period of butter samples, colour measurements ( $L, a, b$ values) were made using Minolta colorimeter (Chroma Meter CR200, Osaka, Japan). Measurements were made in three different locations based on the average value of the readings. Before the measurements, the device was calibrated with white calibration plate and all measurements were carried out by using chromium drying containers on a white board.

\section{Determination of vitamin $A$ and $\beta$-carotene amounts}

The method described by Hulshof et al. (2006) was adapted as follows with slight modifications. The concentrations of $\beta$-carotene and vitamin $A$ in butter samples was calculated by the external standard method using a $\beta$-carotene and vitamin A standards (Sigma Aldrich) and expressed as $\mu \mathrm{g}$ of $\beta$-carotene and vitamin A per $100 \mathrm{~g}$ of sample on a dry weight basis (Çakmakçı et al., 2014a).

\section{Sensory analysis}

Butter samples were evaluated using a sensory scale according to the methods of Bernotene et al. (1980) during the storage. Sensory criteria were developed taking the characteristics of butter into consideration. Eight panelists who were familiar with butter and were academic staff (ages were between 30 to 50 ) at the Department of Food Engineering (Atatürk University, Erzurum, Turkey) staffed in the evaluation of butter. Each panelist evaluated the butter samples for the six sensory characteristics including colour, texture, flavour, odour, rancid taste and general acceptability. All sensory characteristics were graded from 1 to 9 (1: poor, 9: excellent) on point scales. Panelists were also instructed to cleanse their palates between samples by using water and bread.

\section{Statistical analysis}

The experimental research design was done as follows: 3 (butter samples made from cows', sheeps' and goats' milk creams) $\times 7$ (storage period) $\times 2$ (replicates). Duncan multiple comparison test was applied to the results of the statistical analysis.

\section{RESULTS AND DISCUSSION \\ Physico-chemical properties and oxidation stability}

The physico-chemical properties of the butter are also related by animal species. Lipids in sheep and goat milk have higher physical characteristics than in cow milk, but physico-chemical indices vary between different reports (Park et al., 2007). Table 1 shows the physico-chemical properties of the butter samples. There was no significant difference in the dry matter and fat contents of $C, S$ and $G$ samples. The results of dry matter and fat content of the butters were similar to those obtained by Sagdic et al. (2004). However, $\mathrm{pH}$, titratable acidity and acid value showed significant differences in all varieties of butter. $\mathrm{C}$ samples had the highest $\mathrm{pH}$ and acid value. Titratable acidity of the $\mathrm{S}$ sample was significantly higher than those of other butters. The acidity and acid values increased during the storage period and the values were statistically determined as different. $\mathrm{pH}$ decreased during storage (Table 1). According to the results of variance analysis on $\mathrm{pH}$, titratable acidity and acid value in the butter samples, butter type, storage period and butter type $\times$ storage period interactions were found significant $(P<0.01)$.

Butter type and storage period were found significant $(P<0.01)$ in all fat constants of the all butter, whereas butter type $\times$ storage period interactions was not significant $(P>0.05)$ in terms of Polenske number and refractive index. Reichert-Meissl number and Polenske number are used to determine the presence of short chain fatty acids (Kurt et al., 2007). In this study, Reichert Meissl numbers and Polenske numbers varied from 25.57 to 26.68 and from 1.01 to 2.15 in $\mathrm{C}$ and $\mathrm{S}$ samples, respectively. The highest values for Reichert Meissl number had sheep, goat and cow butter samples, respectively. The highest value for Polenske number had goat 
butter sample and the cow butter sample had the lowest value (Table 2). The values increased in three types of butter during the storage period and compare favourably to those obtained by Sagdic et al. (2004) and Hayaloğlu (1999) and Şengül et al. (1998). Goat milk may have higher Reichert Meissl and higher Polenske values than cow milk, suggesting that goat milk fat contains less soluble and more insoluble volatile fatty acid than cow milk fat, although there are different values in the literature for all three species. Cow milk has a higher saponification value and slightly greater refractive index than goat milk, which relates to the longer carbon chains and saturation of the fatty acids (Park et al., 2007). But in our study, goat butter was found a higher saponification value than cow butter. Goat milk has lower iodine values, which reflects its greater amount on lower and unsaturated fatty acid (Park et al., 2007). In this study, the highest value was found in sheep butter. Park et al. (2007) was found similar result. Moreover, the highest values of saponification and Polenske number were found in the goat butter (Table 2). Short and medium chain fatty acids occur as a result of lipolysis; it causes rancidity which negatively affects the flavour of milk and dairy products (Deeth, 2006). Cow butter had the highest value of refractive index followed by sheep butter and goat butter. Average refractive index results were found in $G$ (1.4571), $S$ (1.4576) and C (1.4587) samples, starting from the lowest, respectively. Similarly, during the storage period values of refractive index increased (Table 2).

Table 1. Chemical properties of butter samples

\begin{tabular}{|c|c|c|c|c|c|c|}
\hline $\begin{array}{l}\text { Butter } \\
\text { types }\end{array}$ & $\begin{array}{c}\begin{array}{c}\text { Storage time } \\
\text { (days) }\end{array} \\
\end{array}$ & Dry matter $(\%)$ & Fat $(\%)$ & $\mathrm{pH}$ & $\begin{array}{c}\text { Titratable } \\
\text { acidity }(\%)\end{array}$ & $\begin{array}{c}\text { Acid value (mg } \\
\mathrm{KOH} / \mathrm{g} \text { fat })\end{array}$ \\
\hline \multirow{7}{*}{$\mathrm{C}$} & 1 & $82.90 \pm 0.14$ & $81.65 \pm 0.21$ & $5.67 \pm 0.00$ & $0.13 \pm 0.01$ & $0.56 \pm 0.00$ \\
\hline & 15 & $82.88 \pm 0.04$ & $81.65 \pm 0.21$ & $5.66 \pm 0.00$ & $0.17 \pm 0.02$ & $0.58 \pm 0.00$ \\
\hline & 30 & $82.92 \pm 0.09$ & $81.80 \pm 0.00$ & $5.64 \pm 0.02$ & $0.21 \pm 0.00$ & $0.60 \pm 0.00$ \\
\hline & 45 & $82.90 \pm 0.15$ & $81.90 \pm 0.14$ & $5.53 \pm 0.01$ & $0.23 \pm 0.00$ & $0.82 \pm 0.00$ \\
\hline & 60 & $82.93 \pm 0.07$ & $81.90 \pm 0.14$ & $5.48 \pm 0.02$ & $0.26 \pm 0.00$ & $0.97 \pm 0.00$ \\
\hline & 75 & $82.79 \pm 0.08$ & $81.50 \pm 0.00$ & $5.44 \pm 0.01$ & $0.28 \pm 0.00$ & $1.10 \pm 0.00$ \\
\hline & 90 & $82.82 \pm 0.03$ & $81.50 \pm 0.00$ & $5.35 \pm 0.00$ & $0.31 \pm 0.00$ & $1.27 \pm 0.00$ \\
\hline Average & & $82.88 \pm 0.09 \mathrm{a}$ & $81.70 \pm 0.19 \mathrm{a}$ & $5.54 \pm 011 \mathrm{c}$ & $0.23 \pm 0.06 \mathrm{a}$ & $0.84 \pm 0.26 \mathrm{c}$ \\
\hline \multirow{7}{*}{ S } & 1 & $82.94 \pm 0.06$ & $81.65 \pm 0.21$ & $4.97 \pm 0.00$ & $0.31 \pm 0.00$ & $0.45 \pm 0.00$ \\
\hline & 15 & $82.88 \pm 0.02$ & $81.90 \pm 0.14$ & $4.94 \pm 0.00$ & $0.32 \pm 0.00$ & $0.47 \pm 0.00$ \\
\hline & 30 & $82.84 \pm 0.06$ & $81.65 \pm 0.21$ & $4.92 \pm 0.00$ & $0.34 \pm 0.01$ & $0.58 \pm 0.00$ \\
\hline & 45 & $82.94 \pm 0.10$ & $81.80 \pm 0.00$ & $4.89 \pm 0.00$ & $0.36 \pm 0.00$ & $0.81 \pm 0.00$ \\
\hline & 60 & $82.88 \pm 0.13$ & $81.90 \pm 0.14$ & $4.87 \pm 0.01$ & $0.39 \pm 0.00$ & $0.97 \pm 0.00$ \\
\hline & 75 & $82.96 \pm 0.01$ & $81.80 \pm 0.00$ & $4.85 \pm 0.01$ & $0.44 \pm 0.00$ & $1.18 \pm 0.00$ \\
\hline & 90 & $82.77 \pm 0.03$ & $81.80 \pm 0.00$ & $4.83 \pm 0.03$ & $0.51 \pm 0.00$ & $1.38 \pm 0.00$ \\
\hline \multirow[t]{2}{*}{ Average } & & $82.89 \pm 0.08 \mathrm{a}$ & $81.78 \pm 0.14 \mathrm{a}$ & $4.89 \pm 0.05 \mathrm{~b}$ & $0.38 \pm 0.06 \mathrm{c}$ & $0.83 \pm 0.34 \mathrm{~b}$ \\
\hline & 1 & $82.76 \pm 0.00$ & $81.50 \pm 0.00$ & $4.96 \pm 0.00$ & $0.22 \pm 0.01$ & $0.45 \pm 0.00$ \\
\hline \multirow{6}{*}{ G } & 15 & $82.88 \pm 0.07$ & $81.65 \pm 0.21$ & $4.91 \pm 0.00$ & $0.25 \pm 0.01$ & $0.47 \pm 0.00$ \\
\hline & 30 & $83.00 \pm 0.01$ & $81.75 \pm 0.35$ & $4.88 \pm 0.00$ & $0.29 \pm 0.01$ & $0.58 \pm 0.00$ \\
\hline & 45 & $82.82 \pm 0.00$ & $81.65 \pm 0.21$ & $4.83 \pm 0.02$ & $0.33 \pm 0.00$ & $0.74 \pm 0.00$ \\
\hline & 60 & $82.82 \pm 0.06$ & $81.80 \pm 0.00$ & $4.80 \pm 000$ & $0.36 \pm 0.00$ & $0.89 \pm 0.00$ \\
\hline & 75 & $82.84 \pm 0.04$ & $81.50 \pm 0.00$ & $4.77 \pm 0.00$ & $0.40 \pm 0.00$ & $1.02 \pm 0.00$ \\
\hline & 90 & $82.88 \pm 0.06$ & $81.65 \pm 0.21$ & $4.76 \pm 0.00$ & $0.43 \pm 0.01$ & $1.19 \pm 0.00$ \\
\hline Average & & $82.85 \pm 0.07 \mathrm{a}$ & $81.64 \pm 0.17 \mathrm{a}$ & $4.84 \pm 0.07 \mathrm{a}$ & $0.32 \pm 0.07 \mathrm{~b}$ & $0.76 \pm 0.27 \mathrm{a}$ \\
\hline Source & D.F. & & & ANOVA & & \\
\hline BT & 2 & 0.60 & 1.07 & $10443.89^{* *}$ & $1024.47 * *$ & $1947.08^{* *}$ \\
\hline S & 6 & 0.82 & 0.87 & $201.44 * *$ & $347.92^{* *}$ & $41352.40^{* *}$ \\
\hline $\mathrm{BT} \times \mathrm{S}$ & 12 & 1.74 & 0.34 & $14.89^{* *}$ & $6.11 * *$ & $347.07^{* *}$ \\
\hline Error & 21 & & & & & \\
\hline Total & 42 & & & & & \\
\hline
\end{tabular}

C:Butter made from cow milk cream; S: Butter made from sheep milk cream; G: Butter made from goat milk cream BT: Butter types; S: Storage time

The difference between the average in the same letter is statistically indistinguishable from each other.

** is significant at $P<0.01$ probability levels. 
Table 2. Fat constants values of butter samples

\begin{tabular}{|c|c|c|c|c|c|c|}
\hline Butter types & $\begin{array}{c}\text { Storage } \\
\text { time (days) }\end{array}$ & $\begin{array}{c}\text { Reichert- } \\
\text { Meissl } \\
\text { number }\end{array}$ & $\begin{array}{l}\text { Polenske } \\
\text { number }\end{array}$ & $\begin{array}{l}\text { Refractive } \\
\text { indice }\end{array}$ & $\begin{array}{c}\text { Saponification } \\
\text { number }\end{array}$ & $\begin{array}{l}\text { Iodine } \\
\text { number }\end{array}$ \\
\hline \multirow{7}{*}{$\mathrm{C}$} & 1 & $25.21 \pm 0.02$ & $0.80 \pm 0.00$ & $1.4585 \pm 0.00$ & $226.25 \pm 0.39$ & $35.10 \pm 0.47$ \\
\hline & 15 & $25.33 \pm 0.02$ & $0.85 \pm 0.07$ & $1.4586 \pm 0.00$ & $226.96 \pm 0.04$ & $34.55 \pm 0.05$ \\
\hline & 30 & $25.55 \pm 0.04$ & $0.95 \pm 0.07$ & $1.4586 \pm 0.00$ & $227.38 \pm 0.12$ & $34.50 \pm 0.15$ \\
\hline & 45 & $25.64 \pm 0.05$ & $1.00 \pm 0.00$ & $1.4586 \pm 0.00$ & $229.23 \pm 0.09$ & $33.96 \pm 0.18$ \\
\hline & 60 & $25.72 \pm 0.02$ & $1.05 \pm 0.07$ & $1.4588 \pm 0.00$ & $230.77 \pm 0.80$ & $33.05 \pm 0.07$ \\
\hline & 75 & $25.77 \pm 0.04$ & $1.20 \pm 0.00$ & $1.4588 \pm 0.00$ & $232.75 \pm 0.26$ & $32.25 \pm 0.22$ \\
\hline & 90 & $25.83 \pm 0.04$ & $1.25 \pm 0.07$ & $1.4590 \pm 0.00$ & $233.97 \pm 0.40$ & $31.62 \pm 0.04$ \\
\hline Average & & $25.57 \pm 0.22 \mathrm{a}$ & $1.01 \pm 0.16 \mathrm{a}$ & $1.4587 \pm 0.00 \mathrm{c}$ & $229.61 \pm 2.88 \mathrm{a}$ & $33.57 \pm 1.25 \mathrm{~b}$ \\
\hline \multirow{7}{*}{ S } & 1 & $26.50 \pm 0.00$ & $1.30 \pm 0.00$ & $1.4573 \pm 0.00$ & $232.25 \pm 0.03$ & $36.79 \pm 0.28$ \\
\hline & 15 & $26.57 \pm 0.08$ & $1.40 \pm 0.00$ & $1.4575 \pm 0.00$ & $232.69 \pm 0.43$ & $36.25 \pm 0.04$ \\
\hline & 30 & $26.62 \pm 0.02$ & $1.45 \pm 0.07$ & $1.4577 \pm 0.00$ & $234.43 \pm 0.28$ & $35.79 \pm 0.21$ \\
\hline & 45 & $26.68 \pm 0.00$ & $1.50 \pm 0.00$ & $1.4577 \pm 0.00$ & $235.16 \pm 0.24$ & $35.28 \pm 0.02$ \\
\hline & 60 & $26.73 \pm 0.02$ & $1.60 \pm 0.00$ & $1.4577 \pm 0.00$ & $236.57 \pm 0.07$ & $34.04 \pm 0.12$ \\
\hline & 75 & $26.79 \pm 0.00$ & $1.70 \pm 0.00$ & $1.4577 \pm 0.00$ & $237.70 \pm 0.44$ & $33.08 \pm 0.04$ \\
\hline & 90 & $26.87 \pm 0.04$ & $1.80 \pm 0.00$ & $1.4580 \pm 0.00$ & $238.85 \pm 0.04$ & $32.31 \pm 0.07$ \\
\hline \multirow[t]{2}{*}{ Average } & & $26.68 \pm 0.12 c$ & $1.53 \pm 0.16 b$ & $1.4576 \pm 0.00 \mathrm{~b}$ & $235.38 \pm 2.38 b$ & $34.79 \pm 1.62 \mathrm{c}$ \\
\hline & 1 & $26.08 \pm 0.02$ & $1.95 \pm 0.07$ & $1.4570 \pm 0.00$ & $234.33 \pm 0.57$ & $33.23 \pm 0.42$ \\
\hline \multirow{6}{*}{ G } & 15 & $26.12 \pm 0.00$ & $2.00 \pm 0.00$ & $1.4571 \pm 0.00$ & $235.66 \pm 0.37$ & $32.30 \pm 0.24$ \\
\hline & 30 & $26.18 \pm 0.00$ & $2.05 \pm 0.07$ & $1.4571 \pm 0.00$ & $235.98 \pm 0.31$ & $31.85 \pm 0.10$ \\
\hline & 45 & $26.25 \pm 0.00$ & $2.15 \pm 0.07$ & $1.4571 \pm 0.00$ & $236.99 \pm 0.28$ & $30.93 \pm 0.16$ \\
\hline & 60 & $26.29 \pm 0.01$ & $2.20 \pm 0.00$ & $1.4572 \pm 0.00$ & $237.56 \pm 0.47$ & $30.22 \pm 0.02$ \\
\hline & 75 & $26.35 \pm 0.00$ & $2.35 \pm 0.07$ & $1.4573 \pm 0.00$ & $239.43 \pm 0.54$ & $29.58 \pm 0.02$ \\
\hline & 90 & $26.42 \pm 0.02$ & $2.40 \pm 0.00$ & $1.4575 \pm 0.00$ & $241.17 \pm 0.28$ & $28.46 \pm 0.18$ \\
\hline Average & & $26.24 \pm 0.11 \mathrm{~b}$ & $2.15 \pm 0.16 c$ & $1.4571 \pm 0.00 \mathrm{a}$ & $237.30 \pm 2.27 \mathrm{c}$ & $30.94 \pm 1.59 \mathrm{a}$ \\
\hline Source & D.F. & & & ANOVA & & \\
\hline BT & 2 & $3897.17 * *$ & $2138.77 * *$ & $253.26^{* *}$ & $1644.88^{* *}$ & $1407.24 * *$ \\
\hline S & 6 & $136.15^{* *}$ & $81.77 * *$ & $5.85^{* *}$ & $294.03^{* *}$ & $369.17 * *$ \\
\hline $\mathrm{BT} \times \mathrm{S}$ & 12 & $8.11 * *$ & 0.27 & 0.24 & $3.90 * *$ & $3.78^{* *}$ \\
\hline Error & 21 & & & & & \\
\hline Total & 42 & & & & & \\
\hline
\end{tabular}

C: Butter made from cow milk cream; S: Butter made from sheep milk cream; G: Butter made from goat milk cream ; BT: Butter types; S: Storage time

The difference between the average in the same letter is statistically indistinguishable from each other.

** is significant at $P<0.01$ probability levels.

PV shows the amount of hydroperoxide which consisted in the primary stage of oxidative deterioration, while TBA value gives the amount of malonaldehyde at the advanced stages of oxidation. It is not possible to detect the malonaldehyde with peroxide tests since the hydroperoxides are transformed into malonaldehydes during the storage period (Atamer, 1993). Oxidative degradation (rancidity), which is known to be influenced by many factors including fatty acid profile, oxygen availability, light and temperature exposure, minor components in the oil/fat (Flakelar et al., 2015).
In this study, the highest value $\left(0.25\right.$ meq $\mathrm{O}_{2} / \mathrm{mg}$ fat) was defined in the butter samples made from goat's milk followed by sheep's and cow's and PV increased during the storage. In the butter samples made from cow's milk was not found 30 days of storage. PV and TBA values of sheep and goat butter were found higher compared to cow butter (Table 3). The highest PV and TBA values were determined in the goat butter followed by sheep and cow butter samples (Fig. 1a and Fig. $1 \mathrm{~b})$. The lowest TBA value was observed on the $1^{\text {st }}$ and $15^{\text {th }}$ days of storage, and it increased during storage (Table 3). The TBA value of cow butter 
was similar to those given by Çakmakçı et al. (2014b). Our PV results were similar to those given by Povolo and Contarini (2003), Öztürk and Çakmakçı (2006), Şenel et al. (2011) and
Çakmakçı et al. (2014b) with the results of PV of cow butter samples. TBA value of sheep butter was similar to those given by Özkanlı and Kaya (2007).

Table 3. Colour properties and oxidation tests results of butter samples

\begin{tabular}{|c|c|c|c|c|c|c|}
\hline $\begin{array}{l}\text { Butter } \\
\text { types }\end{array}$ & $\begin{array}{l}\text { Storage } \\
\text { time } \\
\text { (days) }\end{array}$ & $L$ value & $a$ value & $b$ value & $\begin{array}{l}\mathrm{PV} \text { (meq } \\
\mathrm{O}_{2} / \mathrm{kg} \text { fat }\end{array}$ & $\begin{array}{c}\text { TBA value (mg } \\
\text { malonaldehyde/ } \\
\text { kg fat) }\end{array}$ \\
\hline \multirow{7}{*}{$\mathrm{C}$} & 1 & $84.63 \pm 0.16$ & $-3.85 \pm 0.08$ & $20.45 \pm 0.05$ & nd & $0.01 \pm 0.00$ \\
\hline & 15 & $84.66 \pm 0.00$ & $-3.70 \pm 0.01$ & $19.80 \pm 0.02$ & nd & $0.02 \pm 0.00$ \\
\hline & 30 & $84.59 \pm 0.02$ & $-3.75 \pm 0.02$ & $19.37 \pm 0.03$ & nd & $0.05 \pm 0.00$ \\
\hline & 45 & $84.60 \pm 0.06$ & $-3.81 \pm 0.02$ & $18.86 \pm 0.05$ & $0.05 \pm 0.00$ & $0.08 \pm 0.01$ \\
\hline & 60 & $84.62 \pm 0.08$ & $-3.79 \pm 0.00$ & $18.78 \pm 0.04$ & $0.13 \pm 0.02$ & $0.11 \pm 0.00$ \\
\hline & 75 & $84.65 \pm 0.06$ & $-3.82 \pm 0.03$ & $18.73 \pm 0.04$ & $0.20 \pm 0.04$ & $0.13 \pm 0.00$ \\
\hline & 90 & $84.67 \pm 0.00$ & $-3.89 \pm 0.00$ & $18.48 \pm 0.24$ & $0.27 \pm 0.01$ & $0.15 \pm 0.00$ \\
\hline Average & & $84.63 \pm 0.06 \mathrm{c}$ & $-3.80 \pm 0.06 a$ & $19.21 \pm 0.68 c$ & $0.09 \pm 0.10 \mathrm{a}$ & $0.08 \pm 0.05 a$ \\
\hline \multirow{7}{*}{$\mathrm{S}$} & 1 & $83.55 \pm 0.19$ & $-3.84 \pm 0.06$ & $11.84 \pm 0.09$ & nd & $0.02 \pm 0.00$ \\
\hline & 15 & $83.47 \pm 0.14$ & $-3.82 \pm 0.02$ & $11.70 \pm 0.03$ & nd & $0.03 \pm 0.00$ \\
\hline & 30 & $83.49 \pm 0.00$ & $-3.79 \pm 0.06$ & $10.78 \pm 0.04$ & $0.14 \pm 0.02$ & $0.09 \pm 0.01$ \\
\hline & 45 & $83.50 \pm 0.00$ & $-3.81 \pm 0.11$ & $10.71 \pm 0.07$ & $0.27 \pm 0.00$ & $0.19 \pm 0.01$ \\
\hline & 60 & $83.49 \pm 0.13$ & $-3.73 \pm 0.01$ & $10.58 \pm 0.12$ & $0.32 \pm 0.00$ & $0.23 \pm 0.01$ \\
\hline & 75 & $83.61 \pm 0.00$ & $-3.77 \pm 0.05$ & $10.39 \pm 0.02$ & $0.37 \pm 0.00$ & $0.25 \pm 0.00$ \\
\hline & 90 & $83.57 \pm 0.07$ & $-3.65 \pm 0.05$ & $10.28 \pm 0.00$ & $0.49 \pm 0.03$ & $0.27 \pm 0.00$ \\
\hline Average & & $83.53 \pm 0.09 a$ & $-3.77 \pm 0.07 \mathrm{a}$ & $10.90 \pm 0.59 \mathrm{~b}$ & $0.22 \pm 0.18 b$ & $0.15 \pm 0.09 \mathrm{~b}$ \\
\hline \multirow{7}{*}{ G } & 1 & $84.43 \pm 0.02$ & $-3.77 \pm 0.03$ & $9.79 \pm 0.04$ & nd & $0.03 \pm 0.00$ \\
\hline & 15 & $84.47 \pm 0.00$ & $-3.79 \pm 0.02$ & $8.79 \pm 0.06$ & nd & $0.04 \pm 0.00$ \\
\hline & 30 & $84.56 \pm 0.05$ & $-3.69 \pm 0.02$ & $8.61 \pm 0.04$ & $0.18 \pm 0.01$ & $0.14 \pm 0.01$ \\
\hline & 45 & $84.46 \pm 0.00$ & $-3.72 \pm 0.00$ & $8.28 \pm 0.02$ & $0.28 \pm 0.00$ & $0.30 \pm 0.00$ \\
\hline & 60 & $84.47 \pm 0.03$ & $-3.74 \pm 0.05$ & $7.79 \pm 0.00$ & $0.34 \pm 0.00$ & $0.33 \pm 0.01$ \\
\hline & 75 & $84.53 \pm 0.02$ & $-3.80 \pm 0.00$ & $7.68 \pm 0.01$ & $0.42 \pm 0.01$ & $0.39 \pm 0.01$ \\
\hline & 90 & $84.61 \pm 0.00$ & $-3.84 \pm 0.01$ & $7.50 \pm 0.01$ & $0.55 \pm 0.01$ & $0.43 \pm 0.00$ \\
\hline Average & & $84.50 \pm 0.06 \mathrm{~b}$ & $-3.76 \pm 0.05 a$ & $8.35 \pm 0.76 a$ & $0.25 \pm 0.19 \mathrm{c}$ & $0.23 \pm 0.16 \mathrm{c}$ \\
\hline Source & D.F. & & & ANOVA & & \\
\hline BT & 2 & $787.65^{* *}$ & 2.65 & $83997.24^{* *}$ & $393.66^{* *}$ & $964.86 * *$ \\
\hline S & 6 & 1.29 & 1.99 & $541.84 * *$ & $637.71 * *$ & $767.35^{* *}$ \\
\hline $\mathrm{BT} \times \mathrm{S}$ & 12 & 0.51 & $4.21 * *$ & $11.94 * *$ & $28.61 * *$ & $72.47 * *$ \\
\hline Error & 21 & & & & & \\
\hline Total & 42 & & & & & \\
\hline
\end{tabular}

C: Butter made from cow milk cream; S: Butter made from sheep milk cream; G: Butter made from goat milk cream ; BT: Butter types; S: Storage time ; nd: non detectable

The difference between the average in the same letter is statistically indistinguishable from each other.

** is significant at $P<0.01$ probability levels.

The natural yellowish colour of butter, mainly is derived from carotene (provitamin A) in the milk fat, which originates from the feed and animal species. In this study, in the case of three kinds of butter, $L$ and $b$ values were statistically different. The lowest $L$ value was found in the sheep butter (83.53), while the highest $b$ value was found in the cow butter (19.21). $L$ values varied from 83.53 to
84.63 in $\mathrm{S}$ and $\mathrm{C}$ samples, respectively. $b$ values varied from 8.35 to 19.21 in $G$ and $C$ samples, respectively. During the storage period, the change in $L$ value was insignificant and the change in $b$ value was found to be significant. $a$ value showed small fluctuations (Table 3 ). The $b$ value differs for all butter types. Because carotenoids are fat-soluble, fat colour is a function 
of the carotenoid concentration in the butter (Kneifel et al., 1992). Carotenoids play a major role in the colour of dairy products. Goats convert the carotene in their diet to vitamin A more efficiently than cows do, producing whiter milk, cream, and butter (Jerop et al., 2014). Colour differences is mainly due caused by the differing $\beta$-carotene contents. Because, butter samples made from cows' milk contains more $\beta$-carotene, it is more yellow than other butter types. Moreover, the $b$ value decreased during storage in all butter types. $b$ value was higher than the values found by Özkanlı and Kaya (2007) and Krause et al. (2008).

Butter type and storage period were found significant $(P<0.01)$ in terms of vitamin $\mathrm{A}$. The highest amount of vitamin $A$ was found in the sheep butter sample $(19.86 \mu \mathrm{g} / \mathrm{g})$ followed by goat and cow butter samples and it decreased during the storage period (Table 4; Fig. 1c). Vitamin A contents of goat and sheep butter samples are mostly higher than in cow butter (Table 4). Similar result was found by Park et al. (2007). Goats convert all $\beta$-carotene into vitamin A in the milk, for the same reason, goat milk is always whiter than cow milk (Park et al., 2007; Zenebe et al., 2014). The results of vitamin A in the butter samples made from cow's milk were similar to those given by Mallia et al. (2008) and Hulshof et al. (2006). $\beta$-carotene was only found in the butter samples made from cows' milk $(5.03$ $\mu \mathrm{g} / \mathrm{g})$. The results of $\beta$-carotene of the butter samples made from cows' milk were similar to those given by Hewavitharana et al. (1996) and Hulshof et al. (2006).

Table 4. $\beta$-carotene and vitamin A contents of butter samples

\begin{tabular}{lccc}
\hline Butter types & Storage time (days) & $\beta$-carotene $(\mu \mathrm{g} / \mathrm{g})$ & Vitamin A $(\mu \mathrm{g} / \mathrm{g})$ \\
\hline $\mathrm{C}$ & 1 & $5.38 \pm 0.22$ & $17.30 \pm 0.17$ \\
& 30 & $5.10 \pm 0.05$ & $16.78 \pm 0.08$ \\
& 60 & $4.90 \pm 0.07$ & $15.96 \pm 0.14$ \\
\hline Average & 90 & $4.74 \pm 0.12$ & $15.35 \pm 0.21$ \\
\hline & 1 & $5.03 \pm 0.27 \mathrm{a}$ & $16.35 \pm 0.80 \mathrm{a}$ \\
$\mathrm{S}$ & 30 & nd & $20.67 \pm 0.18$ \\
& 60 & nd & $20.03 \pm 0.09$ \\
& 90 & nd & $19.55 \pm 0.09$ \\
Average & & nd & $19.21 \pm 0.14$ \\
\hline & 1 & - & $19.86 \pm 0.59 \mathrm{c}$ \\
G & 30 & nd & $19.76 \pm 0.12$ \\
& 60 & nd & $19.00 \pm 0.19$ \\
\hline Average & 90 & nd & $18.43 \pm 0.04$ \\
\hline Source & & nd & $17.70 \pm 0.25$ \\
\hline BT & D.F. & - & $18.72 \pm 0.81 \mathrm{~b}$ \\
S & 2 & & ANOVA \\
BT $\times$ S & 3 & $8.05^{* *}$ & $1029.27 * *$ \\
Error & 6 & $8.05^{* *}$ & 2.00 \\
Total & 12 & & \\
C: Butt & 24 & &
\end{tabular}

C: Butter made from cow milk cream; S: Butter made from sheep milk cream; G: Butter made from goat milk cream ; BT: Butter types; S: Storage time ; nd: non detectable

The difference between the average in the same letter is statistically indistinguishable from each other.

** is significant at $P<0.01$ probability levels. 

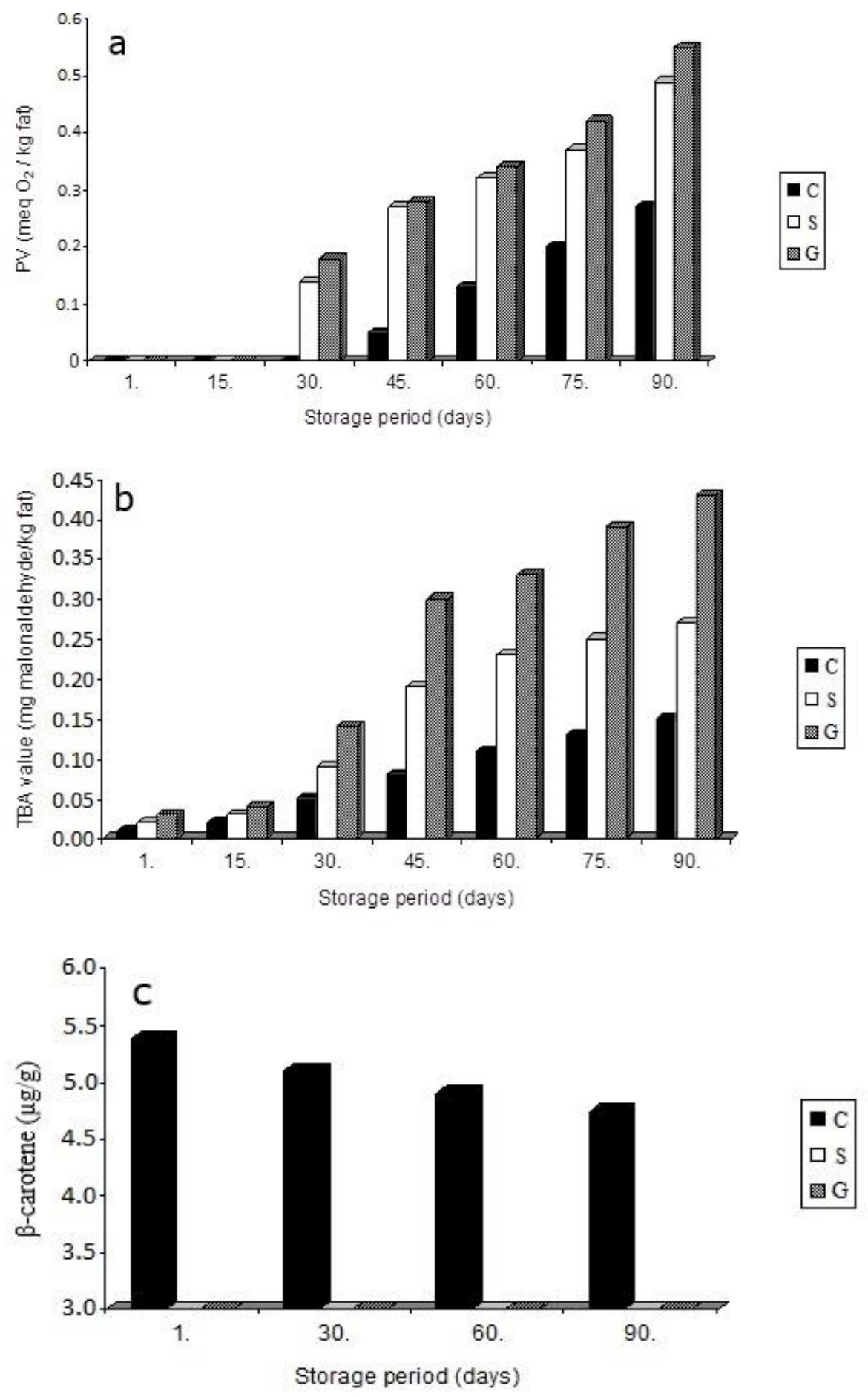

Figure 1 a) The effect of butter type and storage period on peroxide value; b) The effect of butter type and storage period on TBA value; c) The effect of butter type and storage period on $\beta$-carotene C: Butter made from cow's milk cream; S: Butter made from sheep's milk cream; G: Butter made from goat's milk cream 


\section{Sensory characteristics}

Sensory scores for colour, texture, odour, flavour, rancid taste and general acceptability were significantly influenced by the storage period of all butter types (Table 5). Butter type, storage period and butter type $\times$ storage period interaction showed statistically significant effects $(P<0.01)$ on sensory properties (in interaction, except general acceptability). The highest sensory scores in all kinds of butter were determined in the cow butter samples followed by goat and then sheep butter samples. During the storage period, reduction was observed in all sensory properties (Table 5). The reason for this may be due to the increase in the PV during the storage period. The scores of colour, texture and flavour of the butter samples were similar to those given by Şenel et al. (2011). Sensory characteristics showed strong positive correlation with $\mathrm{pH}$ (except rancid taste) and strong negative with titratable acidity. Sensory characteristics also have weak positive correlation with Reichert-Meissl number, refractive indice and iodine number; however, we observed weak negative correlation between Polenske number and sensory characteristics. Saponification number was strong negative correlated with sensory characteristics. Sensory characteristics showed strong negative correlation between PV and TBA value, and strong positive with $b$ value (except rancid taste) (Table 6). If the storage temperature cannot be preserved, there might be some important changes for the butter aroma as a result of lipolysis and oxidation. Sensory characteristics showed strong negative correlation between PV and TBA value, and strong positive with $b$ value (except rancid taste). Lastly, sensory characteristics have weak positive correlation with $L$ value, vitamin $A$ and $\beta$-carotene, and weak negative with $a$ value (Table 6).

Table 5. Sensory characteristics of butter samples

\begin{tabular}{|c|c|c|c|c|c|c|c|}
\hline $\begin{array}{l}\text { Butter } \\
\text { types }\end{array}$ & $\begin{array}{c}\text { Storage time } \\
\text { (days) }\end{array}$ & Colour & Texture & Odour & Flavour & Rancid taste & $\begin{array}{c}\text { General } \\
\text { acceptability }\end{array}$ \\
\hline \multirow{7}{*}{$\mathrm{C}$} & 1 & $8.83 \pm 0.24$ & $8.33 \pm 0.24$ & $8.16 \pm 0.00$ & $8.24 \pm 0.12$ & $9.00 \pm 0.00$ & $8.33 \pm 0.24$ \\
\hline & 15 & $8.33 \pm 0.07$ & $8.00 \pm 0.00$ & $7.87 \pm 0.17$ & $8.01 \pm 0.12$ & $8.29 \pm 0.05$ & $8.24 \pm 0.12$ \\
\hline & 30 & $8.26 \pm 0.07$ & $7.92 \pm 0.11$ & $7.75 \pm 0.00$ & $7.79 \pm 0.11$ & $7.71 \pm 0.19$ & $7.74 \pm 0.08$ \\
\hline & 45 & $8.21 \pm 0.04$ & $7.71 \pm 0.04$ & $7.68 \pm 0.13$ & $7.58 \pm 0.11$ & $7.42 \pm 0.24$ & $7.71 \pm 0.14$ \\
\hline & 60 & $8.20 \pm 0.06$ & $7.66 \pm 0.02$ & $7.56 \pm 0.00$ & $7.41 \pm 0.02$ & $7.16 \pm 0.02$ & $7.45 \pm 0.04$ \\
\hline & 75 & $8.01 \pm 0.15$ & $7.62 \pm 0.08$ & $7.43 \pm 0.00$ & $7.51 \pm 0.02$ & $7.15 \pm 0.00$ & $7.37 \pm 0.12$ \\
\hline & 90 & $7.93 \pm 0.09$ & $7.56 \pm 0.00$ & $7.10 \pm 0.10$ & $7.10 \pm 0.10$ & $6.24 \pm 0.26$ & $7.00 \pm 0.00$ \\
\hline Average & & $8.25 \pm 0.29 c$ & $7.83 \pm 0.27 \mathrm{c}$ & $7.65 \pm 0.32 \mathrm{c}$ & $7.66 \pm 0.37 \mathrm{c}$ & $7.56 \pm 0.85 c$ & $7.69 \pm 0.46 \mathrm{~b}$ \\
\hline \multirow{7}{*}{ S } & 1 & $8.00 \pm 0.00$ & $7.33 \pm 0.00$ & $6.99 \pm 0.23$ & $6.91 \pm 0.12$ & $9.00 \pm 0.00$ & $7.58 \pm 0.35$ \\
\hline & 15 & $7.16 \pm 0.00$ & $7.33 \pm 0.11$ & $6.67 \pm 0.04$ & $6.76 \pm 0.02$ & $7.87 \pm 0.05$ & $7.27 \pm 0.02$ \\
\hline & 30 & $7.00 \pm 0.19$ & $7.14 \pm 0.00$ & $6.47 \pm 0.09$ & $6.35 \pm 0.02$ & $6.56 \pm 0.04$ & $6.64 \pm 0.16$ \\
\hline & 45 & $6.89 \pm 0.05$ & $7.10 \pm 0.10$ & $6.53 \pm 0.31$ & $6.09 \pm 0.08$ & $6.18 \pm 0.00$ & $6.31 \pm 0.42$ \\
\hline & 60 & $6.82 \pm 0.02$ & $6.94 \pm 0.02$ & $6.10 \pm 0.06$ & $5.96 \pm 0.13$ & $6.12 \pm 0.08$ & $6.15 \pm 0.13$ \\
\hline & 75 & $6.46 \pm 0.04$ & $6.70 \pm 0.07$ & $5.99 \pm 0.21$ & $5.68 \pm 0.04$ & $5.52 \pm 0.09$ & $5.93 \pm 0.00$ \\
\hline & 90 & $6.37 \pm 0.08$ & $6.76 \pm 0.11$ & $5.62 \pm 0.08$ & $5.03 \pm 0.04$ & $4.71 \pm 0.04$ & $5.28 \pm 0.31$ \\
\hline Average & & $6.95 \pm 0.52 \mathrm{a}$ & $7.04 \pm 0.25 \mathrm{a}$ & $6.34 \pm 0.46 a$ & $6.11 \pm 0.62 \mathrm{a}$ & $6.56 \pm 1.38 \mathrm{a}$ & $6.45 \pm 0.78 \mathrm{a}$ \\
\hline \multirow{7}{*}{ G } & 1 & $8.49 \pm 0.23$ & $8.49 \pm 0.23$ & $7.79 \pm 0.05$ & $7.62 \pm 0.05$ & $9.00 \pm 0.00$ & $7.95 \pm 0.06$ \\
\hline & 15 & $7.20 \pm 0.17$ & $7.54 \pm 0.05$ & $7.16 \pm 0.12$ & $6.81 \pm 0.14$ & $7.80 \pm 0.14$ & $7.30 \pm 0.20$ \\
\hline & 30 & $6.99 \pm 0.10$ & $7.31 \pm 0.14$ & $6.78 \pm 0.09$ & $6.51 \pm 0.09$ & $6.47 \pm 0.19$ & $6.66 \pm 0.08$ \\
\hline & 45 & $6.82 \pm 0.06$ & $7.07 \pm 0.06$ & $6.79 \pm 0.02$ & $6.17 \pm 0.24$ & $6.32 \pm 0.02$ & $6.38 \pm 0.01$ \\
\hline & 60 & $6.76 \pm 0.02$ & $6.93 \pm 0.00$ & $6.37 \pm 0.08$ & $6.18 \pm 0.09$ & $6.23 \pm 0.02$ & $6.29 \pm 0.06$ \\
\hline & 75 & $6.71 \pm 0.04$ & $7.06 \pm 0.00$ & $5.92 \pm 0.15$ & $5.76 \pm 0.46$ & $5.77 \pm 0.13$ & $5.93 \pm 0.09$ \\
\hline & 90 & $6.46 \pm 0.04$ & $6.92 \pm 0.24$ & $5.78 \pm 0.04$ & $5.57 \pm 0.37$ & $5.48 \pm 0.07$ & $5.34 \pm 0.22$ \\
\hline Average & & $7.06 \pm 0.65 b$ & $7.33 \pm 0.54 b$ & $6.65 \pm 0.67 b$ & $6.37 \pm 0.68 b$ & $6.72 \pm 1.19 \mathrm{~b}$ & $6.55 \pm 0.83 a$ \\
\hline Source & D.F. & \multicolumn{6}{|c|}{ ANOVA } \\
\hline $\mathrm{BT}$ & 2 & $576.38^{* *}$ & $176.91 * *$ & $400.64 * *$ & $355.09^{* *}$ & $308.38^{* *}$ & $204.44 * *$ \\
\hline $\mathrm{S}$ & 6 & $117.28^{* *}$ & $57.08 * *$ & $90.71 * *$ & $69.71 * *$ & $638.08 * *$ & $92.27 * *$ \\
\hline $\mathrm{BT} \times \mathrm{S}$ & 12 & $6.86^{* *}$ & $7.42^{* *}$ & $4.97 * *$ & $3.40^{* *}$ & $16.75^{* *}$ & 2.99 \\
\hline Error & 21 & & & & & & \\
\hline Total & 42 & & & & & & \\
\hline
\end{tabular}

C: Butter made from cow milk cream; S: Butter made from sheep milk cream; G: Butter made from goat milk cream BT: Butter types; S: Storage time; The difference between the average in the same letter is statistically indistinguishable from each other. ; $* *$ is significant at $P<0.01$ probability levels. 


\section{CONCLUSIONS}

In conclusion, from the results obtained in this study butter made from cow milk is preferable than other varieties considering the chemical analysis, oxidation stability and sensory properties. While cows' butter was received the highest scores, sheeps' butter was the lowest scored by panelists due to its rancid and offflavour. Moreover, when these results were evaluated collectively, the amount of vitamin A, oxidation stability and sensory characteristics decreased in all butter samples during the storage period. $\beta$-carotene was determined only in the butter samples made from cows' butter and the values decreased during storage. Therefore, the importance of consuming fresh butter is obvious.

\section{ACKNOWLEDGEMENTS}

The authors thank the Atatürk University Research Fund for supporting this research (BAP-Project Number: 2012/419). Also, the authors thank to Prof. Dr. Ali Adnan Hayaloğlu (Inönü University, Food Engineering Department, Malatya, Turkey) and Prof. Dr. Ümit Demir (Atatürk University, Chemistry Department, Erzurum, Turkey) for their help in vitamin analysis.

\section{REFERENCES}

AOAC (1995). Official Method of Analysis, 16th Edition, Washington, DC, USA.

Atamer, M. (1993). Tereyağ Teknolojisi Uygulama Kllavuzu. Ankara Üniversitesi, Ziraat Fakültesi, Yayın No: 1314, Ankara, Türkiye, s. 10-20.

Barlowska, J., Szwajkowska, M., Litwinczuk, Z., Krol, J. (2011). Nutritional value and technological suitability of milk from various animal species used for dairy production. Compr Rev Food Sci Food Saf, 10(6): 291-302. DOI: 10.1111/j.1541-4337.2011.00163.x

Bernotene, O.P., Grinene, E.K., Ignatavichene, R.B., Rekshtene, A.A., Lyibinskene, Y.S. (1980). Sensory evaluation of butter. Molochnaya Promyshlennost, 10: 26-29.

Çakmakçı, S., Tahmas-Kahyaoglu, D., Erkaya, T., Cebi, K., Hayaloglu, A.A. (2014a). $\beta$-carotene contents and quality properties of set type yoghurt supplemented with carrot juice and sugar. J Food
Process Pres, 38(3): 1155-1163. DOI: $10.9775 / \mathrm{kvfd} .2013 .10550$

Çakmakçı, S., Gündoğdu, E., Dağdemir, E., Erdoğan, Ü. (2014b). Investigation of the possible use of black cumin (Nigella sativa L.) essential oil on butter stability. Kafkas Univ Vet Fak Derg, 20(4): 533-539. DOI: $10.9775 / \mathrm{kvfd} .2013 .10550$

Deeth, H.C. (2006). Lipoprotein lipase and lipolysis in milk. Int Dairy J, 16(6): 555-562. DOI: 10.1016/j.idairyj.2005.08.011

Flakelar, C.L., Luckett, D.J., Howitt, J.A., Doran, G., Prenzler, P.D. (2015). Canola (Brassica napus) oil from Australian cultivars shows promising levels of tocopherols and carotenoids, along with good oxidative stability. J Food Compos Anal, 42: 179-186. DOI: 10.1016/j.jfca.2015.03.010

Haenlein, G.F.W. (2004). Goat milk in human nutrition. Small Rumin Res, 51(2): 155-163. DOI: 10.1016/j.smallrumres.2003.08.010

Hayaloğlu, A.A. (1999). Malatya Yöresinde Kremadan ve Yoğurttan Elde Edilen Çeşitli Tereyağlarının Fizikokimyasal, Mikrobiyolojik ve Duyusal Nitelikleri Üzerine Karşılaştırmalı Bir Araştırma. Çukurova Üniversitesi Fen Bilimleri Enstitüsü Gıda Mühendisliği Anabilim Dalı Yüksek Lisans Tezi, Adana, Türkiye, 85s.

Hewavitharana, A.K., Van Brakel, A.S., Harnett, M. (1996). Simultaneous liquid chromatographic determination of vitamins $A, E$ and $\beta$-carotene in common dairy foods. Int Dairy J, 6(6): 613-624. DOI: 10.1016/0958-6946(95)00057-7

Hulshof, P.J.M., Roekel-Jansen, T., Bovenkampy, P., Westz, C. (2006). Variation in retinol and carotenoid content of milk and milk products in The Netherlands. J Food Compos Anal, 19(1): 6775. DOI: $10.1016 /$ j.jfca.2005.04.005

IDF (International Dairy Federation) (2008). Nutritional quality of milkfat. International (Dairy Nutrition Website); pp 1-10.

Jerop, R., Kosgey, I.S., Ogola, T.D.O., Opondo, F.A. (2014). Consumers' perceptions towards goat's milk: Exploring the attitude amongst consumers and its implication for a dairy goat breeding programme in Siaya County, Kenya. EJBM, 6: 221-229. 
Karabulut, I. (2010). Effects of $\alpha$-tocopherol, $\beta$ carotene and ascorbyl palmitate on oxidative stability of butter oil triacylglycerols. Food Chem, 123(3): 622-627. DOI: 10.1016/j.foodchem.2010.04.080

Kashaninejad, M., Razavi, S.M.A., Tehrani, M.M., Kashaninejad, M. (2017). Effect of extrusion conditions and storage temperatureon texture, colour and acidity of butter. Int J Dairy Technol, 70(1): 102-109. DOI: 10.1111/1471-0307.12273

Kneifel, W., Ulberth, F., Chaffer, E. (1992). Tristimulus colour reflectance measurement in milk and dairy products. Le Lait, 72(4): 383-391. DOI: 10.1051/lait:1992427

Krause, A.J., Miracle, R.E., Sanders, T.H., Dean, L.L., Drake, M.A. (2008). The effect of refrigerated and frozen storage on butter flavor and texture. J Dairy Sci, 91(2): 455-465. DOI: 10.3168/jds.2007-0717.

Kurt, A., Çakmakçı, S., Çağlar, A. (2007). Süt ve Mamülleri Muayene Analiz. Metotlar Rebberi. Atatürk Üniversitesi, Ziraat Fakültesi Yayın No: 257, Erzurum, Türkiye, s. 124-137.

Lim, S.H., Kim, H.R., Choi, S.J., Moon, T.W. (2015). Lipid oxidation of sodium caseinatestabilized emulsion-gels prepared using microbial transglutaminase. Food Sci Biotechnol, 24(6): 20232026. DOI: $10.1007 /$ s10068-015-0267-9

Mallia, S., Piccinali, P., Rehberger, B., Badertscher, R., Escher, F., Schlichtherle-Cerny, H. (2008). Determination of storage stability of butter enriched with unsaturated fatty acids/conjugated linoleic acids (UFA/CLA) using instrumental and sensory methods. Int Dairy J, 18(10-11): 983-993. DOI: 10.1016/j.idairyj. 2008.05.007

Özkanl1, O., Kaya, A. (2007). Storage stability of butter oils produced from sheep's nonpasteurized and pasteurized milk. Food Chem, 100(3): 1026-1031. DOI: 10.1016/j.foodchem. 2005.10.052

Öztürk, S., Çakmakçı, S. (2006). The effect of antioxidants on butter in relation to storage temperature and duration. Eur J Lipid Sci Tech, 108(11): 951-959. DOI: 10.1002/ejlt.200600089
Park, Y.W., Juárez, M., Ramos, M., Haenlein, G.F.W. (2007). Physico-chemical characteristics of goat and sheep milk. Small Rumin Res, 68(1-2): 88-113. DOI: 10.1016/j.smallrumres.2006.09.013

Poutzalis, S., Anastasiadou, A., Nasopoulou, C., Megalemou, K., Sioriki, E., Zabetakis, I. (2016). Evaluation of the in vitro anti-atherogenic activities of goat milk and goat dairy products. Dairy Sci Technol, 96(3): 317-327. DOI: 10.1007/s13594-015-0266-x

Povolo, M., Contarini, G. (2003). Comparison of solid-phase microextraction and purge-and-trap methods for the analysis of the volatile fraction of butter. J Chromatogr A, 985(1-2): 117-125. DOI: 10.1016/S0021-9673(02)01395-X

Raynal-Ljutovac, K., Lagriffoul, G., Paccard, P., Guillet, I., Chilliard, Y. (2008). Composition of goat and sheep milk products. Small Rumin Res, 79(1): 57-72. DOI: 10.1016/j.smallrumres. 2008.07.009

Rodríguez, A., Bunger, A., Castro, E., Sousa, I., Empis, J. (2003). Development and optimization of cultured goat cream butter. I Am Oil Chem Soc, 80(10): 987-992. DOI: $10.1007 / \mathrm{s} 11746-003-$ 0808-8

Sagdic, O., Donmez, M., Demirci, M. (2004). Comparison of characteristic and fatty acid profiles of Traditional Turkish Yayik butters produced from goats', ewes' or cows' milk. Food Control, 15(6): 485-490. DOI: 10.1016/j.foodcont. 2003.07.003

Șenel, E., Atamer, M., Öztekin, Ș.F. (2011). The oxidative and lipolytic stability of Yaylk butter produced from different species of mammals milk (cow, sheep, goat) yoghurt. Food Chem, 127(1): 333-339. DOI: 10.1016/j.foodchem.2011.01.012

Şengül, M., Çakmakçı, S., Ünsal, M. (1998). Trabzon tereyağlarının bazı fiziksel ve kimyasal özelliklerinin tespiti. Türkiye V. Süt ve Süt Ürünleri Sempozyumu: Geleneksel Süt Ürünleri, 21-22 Mayıs 1998, Tekirdağ, Türkiye, 427s.

Zenebe, T., Ahmed, N., Kabeta, T., Kebede, G. (2014). Review on medicinal and nutritional values of Goat milk. Acad J Nutr, 3(3): 30-39. DOI: 10.5829/idosi.ajn.2014.3.3.93210 